Jurnal Keperawatan Silampari

Volume 4, Nomor 1, Desember 2020

e-ISSN: 2581-1975

p-ISSN: 2597-7482

DOI: https://doi.org/10.31539/jks.v4i1.1551

\title{
PERSEPSI PERILAKU CARING OLEH PERAWAT BERHUBUNGAN DENGAN STRES KERJA
}

\author{
Roisul Umam \\ Universitas Airlangga \\ umam.raysa@gmail.com
}

\begin{abstract}
ABSTRAK
Penelitian ini bertujuan untuk menganalisis hubungan antara stres kerja perawat dengan persepsi perilaku caring. Metode dalam penelitian ini menggunakan desain penelitian analitik korelasi dengan pendekatan cross-sectional. Hasil analisis dengan menggunakan uji korelasi spearman, diperoleh nilai $r$ hitung sebesar 0.876 dan nilai signifikansi Sig.(2-tailed) sebesar 0.001 (<0.05). Simpulan, stres kerja perawat memiliki berhubungan secara bermakna dengan persepsi perilaku caring di RSI Sakinah Mojokerto.
\end{abstract}

Kata kunci: Perawat, Persepsi Perilaku Caring, Stress

\section{ABSTRACT}

This study aims to analyze the relationship between nurses' job stress and perceptions of caring behavior. The method in this study used a correlation analytic research design with a cross-sectional approach. The analysis results using the Spearman correlation test obtained the calculated $r$-value of 0.876 and a significance value of Sig. (2-tailed) of 0.001 (<0.05). In conclusion, nurses' work stress has a significant relationship with the perception of caring behavior at RSI Sakinah Mojokerto.

Keywords: Nurse, Perceptions of Caring Behavior, Stress

\section{PENDAHULUAN}

Hasil penelitian Urzia \& Jannah (2020) tentang persepsi pasien terhadap perilaku caring perawat di rumah sakit menunjukkan bahwa terdapat sebanyak 36 pasien $(81,8 \%)$ memiliki persepsi tinggi terhadap perilaku caring perawat, sedangkan 8 pasien $(18,2 \%)$ memiliki persepsi sedang dan tidak ada pasien yang memiliki persepsi rendah terhadap perilaku caring perawat di Rumah Sakit Prince Nayef Bin Abdul Aziz Universitas Syiah Kuala Banda Aceh. Hasil penelitian Persatuan Perawatan Nasional Indonesia (2016) menyatakan bahwa sebesar 50,9\% perawat di 4 provinsi di Indonesia mengalami stres kerja, dengan keluhan yaitu sering merasa pusing dan lelah, kurang waktu istirahat, gaji yang rendah, beban kerja yang tinggi dan menyita waktu, serta insentif yang tidak sesuai (Hangewa et al., 2020).

Berdasarkan hasil penelitian Firmansyah et al., (2019) menunjukkan perilaku caring perawat sebagian besar $52,1 \%$ klien menilai perilaku caring perawat cukup. Hal tersebutebut dipengaruhi oleh persepsi klien terhadap pandangan perawat, sehingga klien 
menilai perawat dalam perilaku caring masih cukup. Perilaku caring yang cukup dari pelayanan yang di berikan oleh perawat, klien akan cenderung memiliki persepsi yang baik terhadap perawat.

Persepsi perilaku caring dapat diartikan sebagai suatu manifestasi dari perhatian kepada orang lain, yang berpusat pada orang, menghormati harga diri dan kemanusiaan, komitmen untuk mencegah terjadinya status yang memburuk, dan menghormati orang lain (Brewer \& Watson, 2018). Keperawatan merupakan ilmu pengetahuan dan suatu seni yang terfokuskan pada promosi kualitas hidup yang didefinisikan oleh orang atau keluarga, melalui seluruh pengalaman hidupnya dari kelahiran sampai asuhan pada kematian. Seorang perawat dituntut untuk mampu memahami setiap respon yang berbeda dari pasien terhadap rasa sakit yang dialaminya dan memberikan pelayanan kesehatan yang tepat dalam setiap respon yang berbeda baik yang sedang terjadi maupun yang akan terjadi.

Perilaku persepsi caring dapat ditunjukkan dalam hubungan interpersonal yaitu hubungan yang terjadi antara perawat dengan pasien, dimana perawat menunjukkan perilaku persepsi caring melalui perhatian, intervensi untuk mempertahankan kesehatan pasien dan energi positif yang diberikan pada pasien. Perilaku persepsi caring meliputi komitmen untuk memberikan pelayanan keperawatan yang didasarkan pada ilmu pengetahuan. Dalam praktiknya, perawat menhadapi tantangan untuk tidak ragu dalam menggunakan pengetahuan yang dimilikinya dalam praktik keperawatan (Ackerman, 2018).

Berdasarkan survey pendahuluan melalui wawancara dengan kepala ruangan IGD diketahui bahwa jumlah perawat pelaksana sebanyak 18 orang dan jumlah kunjungan pasien per hari 45-70 pasien dengan jenis penyakit dan tingkat kegawatan yang berbedabeda. Perawat mengeluh banyak hal yang harus dikerjakan secara cepat dan tepat sehingga sering mengalami kelelahan dan stres. Hasil observasi di IGD didapatkan bahwa kegiatankegiatan yang dilakukan oleh perawat antara lain meliputi membersihkan ruangan, memasang infus, mengambil spesimen darah, melakukan Resusitasi Jantung Paru (RJP), menulis dokumentasi tiap tindakan, menghadapi keluarga pasien yang panik, mengambil berkas-berkas dokumentasi, membersihkan ruangan. Hal itu menunjukkan bahwa kondisi emosional perawat berpengaruh terhadap persepsi pasien, mempengaruhi perilaku persepsi caring perawat. Reaksi emosional yang muncul pada diri perawat dapat berupa stres kerja. Berdasarkan fenomena yang terjadi, perawat memiliki stresor yang tinggi karena perawat setiap hari akan berhadapan dengan aspek lingkungan fisik, psikososial dan sosial yang tinggi dari pekerjaan. Sehingga kemungkinan besar akan terjadi stress pada perawat karena beban kerja yang berlebihan.

Sikap dan perilaku perawat sangat mempengaruhi kondisi dan respon kepuasan pasien. Hal itu menunjukkan bahwa kondisi emosional perawat berpengaruh terhadap persepsi klien, mempengaruhi kinerja perawat dan caring perawat. Reaksi emosional yang muncul pada diri perawat dapat berupa stres kerja. Penelitian tentang perilaku perawat sudah pernah dilakukan, namun penelitian ini berfokus pada perilaku caring perawat dan stress kerja. 


\section{METODE PENELITIAN}

Jenis penelitian ini adalah analitik deskriptif dengan pendekatan cross-sectional, metode penelitian ini untuk mengetahui hubungan antara dua variabel yaitu variabel independen (stres kerja) dan variabel dependen (persepsi perilaku caring). Penelitian ini dilaksanakan di RSI Sakinah Mojokerto pada bulan Januari 2020. Populasi penelitian ini adalah seluruh perawat yang betugas di pelayanan medis di RSI Sakinah Mojokerto sebanyak 158 orang. Pengambilan sampel menggunakan rumus slovin maka didapatkan jumlah sampel sebanyak 62 perawat.

Instrumen penelitian yang digunakan untuk mengukur variabel stres kerja dengan persepsi perilaku caring perawat menggunakan kuesioner yang pernah digunakan sebelumnya yang telah diuji validitasnya, kuesioner yang digunakan dalam penelitian ini terdiri dari 24 pernyataan untuk stres kerja dan 36 pernyataan untuk persepsi perilaku caring perawat dengan menggunakan skala likert 1 sampai dengan 4. Skala 1 untuk jawaban "tidak pernah", skala 2 untuk jawaban "kadang-kadang", skala 3 untuk jawaban "pernah", dan skala 4 untuk jawaban "selalu". Setelah lembar kuesioner diisi oleh responden, peneliti mengumpulkan kembali lembar kuesioner. Analisis bivariat dalam penelitian ini yaitu untuk mengetahui hubungan stres kerja dengan persepsi perilaku caring pada perawat. Peneliti menggunakan uji korelasi Spearman dengan tingkat kemaknaan $95 \%$ $(\alpha=0,05)$.

\section{HASIL PENELITIAN}

Tabel 1.

Distribusi Responden $(\mathrm{n}=62)$

\begin{tabular}{lcc}
\hline Karakteristik Responden & Frekuensi & $\%$ \\
\hline Kelompok Usia (Tahun) & & \\
1. $20-30$ & 17 & 27.4 \\
2. $31-40$ & 23 & 37.1 \\
3. 41-50 & 14 & 22.5 \\
4. $>50$ & 8 & 13.0 \\
\hline Jenis Kelamin & & \\
1. Pria & 24 & 38.7 \\
2. Wanita & 38 & 61.3 \\
Tingkat Pendidikan & & \\
1. Diploma III & 18 & 29.1 \\
2. S1 & 35 & 56.5 \\
3. Ners & 9 & 14.4 \\
\hline Masa Kerja (Tahun) & & \\
1. <3 & 9 & 14.5 \\
2. 3-5 & 17 & 27.4 \\
3. >5 & 36 & 58.1 \\
\hline
\end{tabular}

Berdasarkan tabel 1 menunjukkan mayoritas responden berusia 31-40 sebanyak 20 responden $(37,1 \%)$. Mayoritas berjenis kelamin wanita 38 responden $(61,3 \%)$, tingkat pendidikan S1 sebanyak 35 responden $(56,5 \%)$ dan masa kerja >5 tahun sebanyak 36 responden $(58,1 \%)$. 
Tabel. 2

Distribusi Responden Berdasarkan Stres Kerja dan Persepsi Perilaku Caring $(\mathrm{n}=62)$

\begin{tabular}{lcc}
\hline \multicolumn{1}{c}{ Variabel } & Frekuensi & $\%$ \\
\hline Stres Kerja: & & \\
- Ringan & 12 & 19.4 \\
- Sedang & 35 & 56.5 \\
- Berat & 15 & 24.1 \\
Total & 62 & 100 \\
\hline Persepsi perilaku caring: & & \\
- Kurang & 14 & 22.6 \\
- Cukup & 37 & 59.7 \\
- Baik & 11 & 17.7 \\
Total & 62 & 100 \\
\hline
\end{tabular}

Berdasarkan tabel 2 menunjukkan bahwa mayoritas responden mengalami stress kerja sedang yaitu sebanyak 35 responden $(56,5 \%)$ dan perilaku caring mayoritas cukup yaitu sebanyak 37 responden $(59,7 \%)$.

Table. 3

Hubungan Stres Kerja dengan Persepsi Perilaku Caring pada Perawat $(\mathrm{n}=62)$

\begin{tabular}{|c|c|c|c|}
\hline \multicolumn{4}{|c|}{ Correlations } \\
\hline & & Stres Kerja & Persepsi perilaku caring \\
\hline \multirow{3}{*}{ Stres Kerja } & Pearson correlation & 1 & $0.876^{*}$ \\
\hline & Sig.(2-tailed) & & 0.001 \\
\hline & $\mathrm{N}$ & 62 & 62 \\
\hline \multirow{3}{*}{$\begin{array}{l}\text { Persepsi perilaku } \\
\text { caring }\end{array}$} & Pearson correlation & $0.876^{*}$ & 1 \\
\hline & Sig.(2-tailed) & 0.001 & \\
\hline & $\mathrm{N}$ & 62 & 62 \\
\hline
\end{tabular}

Berdasarkan tabel 3 dapat dilihat hasil yang diperoleh nilai r sebesar 0.876 dan nilai signifikansi sebesar 0.001 (<0.05), sehingga dapat disimpulkan bahwa ada hubungan yang signifikan antara stres kerja dengan persepsi perilaku caring pada perawat di RSI Sakinah Mojokerto.

\section{PEMBAHASAN}

\section{Usia}

Berdasarkan tabel 1 distribusi responden yang dilihat dari karakteristik berdasarkan usia, hasil menunjukkan bahwa perawat di RSI Sakinah Mojokerto paling banyak usia 3140 tahun (37.1\%). Menurut Kumbawedi et al., (2016) usia produktif seorang karyawan berada dalam rentang antara 15 tahun sampai 65 tahun, sehingga dapat terlihat responden dalam penelitian ini tergolong dalam usia produktif. Usia seseorang mempengaruhi tingkat produktivitasnya, semakin meningkat usia pekerjaan maka semakin tinggi juga tingkat produktivitasnya dan jika usia karyawan memasuki lanjut usia maka produktivitasnya menurun karena dipengaruhi oleh beberapa faktor seperti fisik dan status kesehatannya. 


\section{Jenis Kelamin}

Berdasarkan tabel 1 distribusi responden dilihat dari karakteristik berdasarkan jenis kelamin, hasil menunjukan bahwa perawat di RSI Sakinah Mojokerto paling banyak adalah jenis kelamin wanita dengan jumlah 38 perawat (61.3\%). Hal ini sejalan dengan penelitian sebelumnya yang dilakukan oleh yang menunjukkan bahwa mayoritas responden berjenis kelamin wanita dengan presentase $85,5 \%$. Secara psikologi, perempuan memiliki sifat atau naluri keibuan yang dibutuhkan dalam melayani, sehingga diharapkan sifat perawat perempuan lebih sabar dan perhatian dalam memberikan pelayanan (Nopa, 2016; Hangewa et al., 2020).

\section{Tingkat Pendidikan}

Berdasarkan tabel 1 distribusi responden dilihat dari karakteristik berdasarkan tingkat pendidikan, hasil menunjukan bahwa perawat di RSI Sakinah Mojokerto mayoritas pendidikan terakhir S1 dengan jumlah 35 perawat (56.5\%). Menurut Hasrul \& Muin (2017) kemampuan seorang perawat dipengaruhi oleh tingkat pendidikannya. Pendidikan yang tinggi dapat meningkatkan kematangan intelektual seseorang sehingga pengetahuan yang dimiliki dapat dikembangkan dan diterapkan dalam pelayanan kesehatan yang diberikan kepada pasien.

\section{Masa Kerja}

Berdasarkan tabel 1 distribusi responden dilihat dari karakteristik berdasarkan masa kerja, hasil menunjukkan bahwa perawat di RSI Sakinah Mojokerto mayoritas dengan masa kerja >5 tahun sebanyak 36 responden (58.1\%). Hasil penelitian Febriani (2019) tentang gambaran stres kerja pada perawat di ruang rawat inap jiwa rumah sakit khusus daerah provinsi sulawesi selatan didapatkan bahwa kebanyakan responden memiliki lama bekerja 1-5 tahun sebanyak 28 responden (72\%). Menurut Adiwijaya \& Widyaisawara (2019) lama bekerja bisa mempengaruhi kinerja seseorang. Semakin lama seseorang bekerja maka semakin tinggi pula tingkat kedewasaannya dalam mengelola setiap masalah yang terjadi ditempat kerja.

\section{Stres Kerja dan Perilaku Caring}

Stres kerja merupakan masalah yang muncul saat seseorang melakukan interaksi dengan lingkungan kerjanya. Tinggi rendahnya stres kerja yang dialami oleh seseorang tergantung dari bagaimana seseorang tersebut melakukan manajemen stres. Berdasarkan hasil penelitian dari Hangewa et al., (2020) menyatakan bahwa perawat pelaksana di RSUD Sragen mempunyai tingkat stres yang rendah $77,8 \%$, sebesar $20 \%$ perawat mempunyai stres sedang dan 2,2\% perawat mempunyai stres yang tinggi. Data tersebut berdasarkan dari penggabungan stres secara keseluruhan baik karena faktor eksternal organisasi, faktor individu maupun faktor internal organisasi. Kondisi stres yang dibiarkan akan mempengaruhi kinerja perawat, bahkan dapat mengancam kemampuannya untuk mengatasi lingkungan. Berdasarkan hasil penelitian stres kerja perawat yang bekerja di ruang RSI Sakinah Mojokerto, terdapat lebih banyak mengalami stres kerja sedang seperti perawat yang mengalami sakit kepala ketika bekerja, mudah tersinggung, jenuh, kelelahan, mudah marah, sulit untuk tidur karena banyak pikiran tentang pekerjaan dan sering menunda tugas pekerjaan yang menjadi tanggung jawabnya. 
Perilaku caring berdasarkan gender dan area praktik tidak terdapat perbedaan secara signifikan. Penelitian ini menunjukkan bahwa sebagian besar perawat belum menunjukkan persepsi perilaku caring yang sesuai dengan kesepuluh faktor karatif yang merupakan faktor-faktor pembentuk persepsi perilaku caring sehingga kebutuhan biofisik, psikososial, spiritual dan interpersonal pada pasien dapat terpenuhi. Berdasarkan hasil penelitian persepsi perilaku caring pada perawat yang bekerja di RSI Sakinah Mojokerto, sebagian besar memiliki persepsi perilaku caring yang cukup, antara lain seperti perawat tidak menerima ekspresi perasaan positif dan negatif pasien atau keluarga, mengidentifikasi masalah yang dihadapi pasien, mendiskusikan masalah yang dikhawatirkan pasien dan kadang-kadang untuk memberikan solusi akan keluhan maupun perasaan yang diutarakan oleh pasien. Berikut adalah hasil uji analisis bivariat antara hubungan stres kerja dengan persepsi perilaku caring.

Berdasarkan tabel 3 dapat dilihat hasil yang diperoleh nilai $\mathrm{r}$ sebesar 0.876 dan nilai signifikansi sebesar $0.001(<0.05)$, sehingga dapat disimpulkan bahwa ada hubungan yang signifikan antara stres kerja dengan persepsi perilaku caring pada perawat di RSI Sakinah Mojokerto. Pada penelitian ini, terdapat korelasi stres kerja dengan persepsi perilaku caring pada perawat adalah sedang, sebesar 0.876 dengan nilai $\mathrm{p}$ value 0.001 , yang menunjukkan koefisien korelasi bernilai positif artinya semakin berat stres kerja perawat maka semakin kurang baik persepsi perilaku caring perawat yang dilakukan. Berdasarkan hal tersebut peneliti berasumsi bahwa salah satu hal yang menyebabkan ada hubungan antara stres kerja dengan persepsi perilaku caring ini yang mempengaruhi adalah faktor usia, perawat dengan usia rentang 31 sampai 40 tahun sebanyak 23 perawat karena usia produktif yang memiliki beban kerja yang berlebihan dalam merawat pasien kritis mempunyai tingkat stres kerja sedang sehingga perilaku persepsi caring yang perawat terapkan masih tergolong cukup jika dibandingkan dengan perawat yang berusia lebih tua.

Menurut Firmansyah et al., (2019) menyatakan bahwa usia muda juga berhubungan dengan tingkat pengetahuan dan kesiapan perawat dalam menangani pasien. Hal ini menunjukkan bahwa, walaupun perawat memiliki stres kerja sedang tetapi dengan usia yang muda dapat meningkatnya pengetahuan dalam merawat pasien atau dalam pemberian asuhan keperawatan sehingga perilaku persepsi caring yang perawat terapkan tergolong cukup. Kurangnya sikap perawat yang sabar, patuh dan bertanggung jawab akan menunjukkan kinerja yang kurang baik dari seorang perawat sehingga baik dalam keadaan lelah atau tidak, perawat tetap menunjukkan persepsi perilaku caring yang kurang baik.

Pada perawat yang memiliki stres kerja yang berat maka persepsi perilaku caring yang dilakukan juga semakin kurang baik. Ada beberapa faktor yang dapat mempengaruhi persepsi perilaku caring seorang perawat dalam pemberian asuhan keperawatan. Stres kerja yang berat dapat mempengaruhi persepsi perilaku caring yang dilakukan oleh perawat untuk mengambil keputusan atau bersikap dalam memberikan asuhan keperawatan, oleh karena itu persepsi perilaku caring yang dilakukan oleh perawat akan menimbulkan kurangnya waktu untuk mendengarkan keluhan pasien, kurangnya perhatian kepada pasien, kurangnya mengahargai perasaan pasien, kurangnya pemenuhan kebutuhan dasar pasien dan kurangnya memfasilitasi pasien untuk bersosialisasi dengan lingkungan. Hasil penelitian dari Hangewa et al., (2020) menyatakan bahwa perilaku caring membantu perawat mengenali intervensi yang baik, dan kemudian menjadi perhatian dan petunjuk untuk memberikan perilaku caring nantinya. 
Dari hasil penelitian di RSI Sakinah Mojokerto, menyatakan bahwa adanya stres kerja yang sedang bagi perawat. Beberapa pasien mengeluhkan bahwa perawat sering menunjukkan kurangnya keramahan, kesabaran, peduli, perhatian, kepekaan, kecepatan dan ketepatan dalam menanggapi permasalahan pasien. Selain itu didapatkan informasi dari survey awal bahwa perawat mengeluhkan adanya stres kerja yang berlebihan di ruang IGD sehingga tidak dapat melakukan persepsi perilaku caring dengan baik. Hal itu menunjukkan bahwa kondisi emosional perawat berpengaruh terhadap persepsi pasien dan mempengaruhi persepsi perilaku caring pada perawat. Reaksi emosional yang muncul pada perawat dapat berupa stres kerja, sehingga akan mempengaruhi kondisi persepsi perilaku caring pada pasien seperti kadang-kadang merasakan apa yang dirasakan pasien, berbicara yang sopan, memberikan semangat kepada pasien agar dapat sembuh, memberikan waktu dan mendengarkan keluhan pasien, memfasilitasi pasien untuk bersosialisasi dengan lingkungan dan membantu pasien dalam pemenuhan kebutuhan sehari-hari misalnya makan, minum, personal hygine pada pasien. Sehingga dapat disimpulkan bahwa terdapat hubungan stres kerja dengan persepsi perilaku caring pada perawat di RSI Sakinah Mojokerto.

\section{SIMPULAN}

Stres kerja perawat berhubungan secara bermakna dengan persepsi perilaku caring di RSI Sakinah Mojokerto.

\section{SARAN}

Pihak rumah sakit diharapkan dapat menggunakan hasil penelitian ini sebagai bahan referensi mengenai hubungan stres kerja dengan persepsi perilaku caring oleh perawat di RSI Sakinah Mojokerto, karena perilaku caring oleh perawat ini dapat mempengaruhi kepuasan pasien rumah sakit. Bagi peneliti selanjutnya diharapkan dapat mengembangkan atau meneliti masalah-masalah lain yang berkaitan dengan peningkatan mutu pelayanan keperawatan persepsi perilaku caring pada pasien.

\section{DAFTAR PUSTAKA}

Ackerman, L. (2018). Caring Science Education: Measuring Nurses Caring Behaviors. International Journal of Caring Science, 12(1), 572-583. http://search.ebscohost.com/login.aspx?direct=true \&db=rzh\&AN=136698227\&site=e host-live

Adiwijaya, \& Widyaisawara. (2019). Hubungan Lama Bekerja dan Motivasi terhadap Kinerja Pegawai. Jurnal Bisnis Administrasi, 7(2), 65-70. https://doi.org/10.1017/CBO9781107415324.004

Brewer, B. B., \& Watson, J. (2018). Evaluation of Authentic Human Caring Professional Practices. Journal of Nursing Administration, 45(12), 622-627. https://doi.org/10.1097/NNA.0000000000000275

Febriani, S. (2019). Gambaran Stres Kerja pada Perawat di Ruang Rawat Inap Jiwa Rumah Sakit Khusus Daerah Provinsi Sulawesi Selatan. Sinergitas Multidisiplin Ilmu Pengetahuan dan Teknologi, 2(2622-0520), 35-43. http://repositori.uinalauddin.ac.id/8166/ 
Firmansyah, C. S., Noprianty, R., \& Karana, I. (2019). Perilaku Caring Perawat Berdasarkan Teori Jean Watson di Ruang Rawat Inap. Jurnal Kesehatan Vokasional, 4(1), 33. https://doi.org/10.22146/jkesvo.40957

Hangewa, N., Bawotong, J. S., Katuuk, M. E., Studi, P., Keperawatan, I., Kedokteran, F., \& Sam, U. (2020). Stres Kerja dengan Persepsi Perilaku Caring pada Perawat. Jurnal Keperawatan, $8(1)$, 59-67. https://ejournal.unsrat.ac.id/index.php/jkp/article/view/28412

Hasrul, H., \& Muin, R. (2017). Hubungan Tingkat Pengetahuan Perawat terhadap Pelaksanaan Asuhan Keperawatan Spiritual di Ruang Perawatan Rumah Sakit Nene Mallomo Kabupaten Sidenreng Rappang. Jurnal Keperawatan Muhammadyah, 2(2), 68-73. 10.30651/jkm.v2i1.911

Kumbawedi, L. S., Suwendra, I. W., \& Susila, G. P. A. J. (2016). Pengaruh Umur, Pengalaman Kerja, Upah, Teknologi dan Lingkungan Kerja terhadap Produktivitas Karyawan. E-Journal Bisma, 4. https://doi.org/10.1093/neuonc/now081.50

Urzia, U., \& Jannah, N. (2020). Persepsi Pasien terhadap Perilaku Caring Perawat Dirumah Sakit Patient Perception Toward the Nurse Caring At Hospital. JIM FKep, IV(2), 132-140. https://etd.unsyiah.ac.id/index.php?p=show_detail\&id=66034 